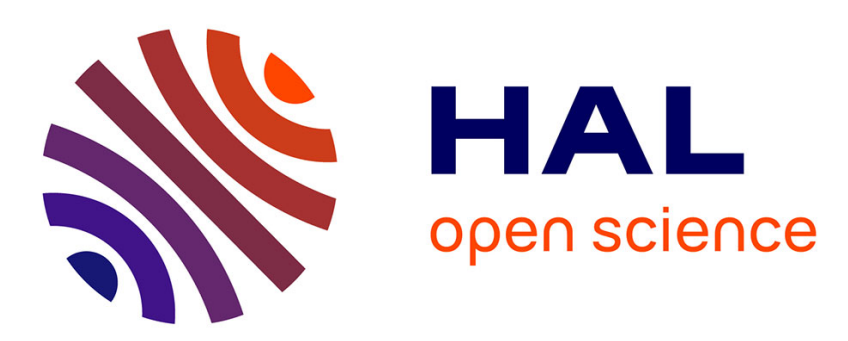

\title{
Toward building energy management: Electric analog modeling for thermal behavior simulation
}

\author{
Hoang-Anh Dang, Benoit Delinchant, Frédéric Wurtz
}

\section{To cite this version:}

Hoang-Anh Dang, Benoit Delinchant, Frédéric Wurtz. Toward building energy management: Electric analog modeling for thermal behavior simulation. Sustainable Energy Technologies (ICSET), 2016 IEEE International Conference on, 2016, hanoi, Vietnam. pp.246-250, 10.1109/ICSET.2016.7811790 . hal-02330354

\section{HAL Id: hal-02330354 \\ https://hal.science/hal-02330354}

Submitted on 22 Apr 2020

HAL is a multi-disciplinary open access archive for the deposit and dissemination of scientific research documents, whether they are published or not. The documents may come from teaching and research institutions in France or abroad, or from public or private research centers.
L'archive ouverte pluridisciplinaire HAL, est destinée au dépôt et à la diffusion de documents scientifiques de niveau recherche, publiés ou non, émanant des établissements d'enseignement et de recherche français ou étrangers, des laboratoires publics ou privés. 


\section{Toward building energy management: Electric analog modeling for thermal behavior simulation}

\author{
Hoang-Anh Dang \\ HaUI Institute of Technology \\ Hanoi University of Industry \\ Hanoi, Vietnam \\ danghoanganh@haui.edu.vn
}

\author{
Benoit Delinchant and Frederic Wurtz \\ Grenoble Electrical Engineering Laboratory \\ Grenoble University \\ Grenoble, France \\ benoit.delinchant@g2elab.grenoble-inp.fr \\ frederic.wurtz@g2elab.grenoble-inp.fr
}

\begin{abstract}
The most energy in buildings is used for space cooling and heating. Thus, the thermal analysis is necessary to reach thermal comfort and energy efficiency in buildings. In this paper, we present a thermal envelope modeling based on thermalelectrical analogy for thermal behavior simulation. The research object is a real platform inside our laboratory building in France. To illustrate this study, two thermal zone model represent two room of this platform, and they are surrounded by another thermal zones of laboratory building. Their parameters have been identified from envelope properties. Then, these models are implemented in a simple equivalent electric circuit, simulated and validated with measurement data.
\end{abstract}

Keywords-Thermal-Electrical analogy, Thermal behavior, Building simulation, Building energy management

\section{INTRODUCTION}

Nowadays, building energy consumption represents the most important portion of global consumption, and its environmental impacts contribute significantly to the climate change and the global warming. In fact, the building sector is responsible for amounts of energy consumption and of $\mathrm{CO}_{2}$ emission. To reduce this consumption and environmental impacts, more efficient energy sources and better insulation are needed. Moreover, building energy management is necessary and this requires more studies on energy performance and energy modeling of buildings.

In building, the energy consumption is imputable mainly to space heating/cooling, lighting, electric equipment/appliances and water heating. Among those demands, heating and cooling system are the main load in residential and non-residential buildings. Thus, the thermal analysis is necessary to assess building energy performance. In fact, this analysis allows us to simulate thermal behaviors, control heating/cooling loads, predict thermal responses, and design sub-systems. It is consequently helpful to achieve thermal comfort and energy efficiency in buildings [1]. In recent years, there are more researches of building thermal modeling that has been done and could be found in literature. The grey-box modeling, which uses both physical and empirical modeling techniques, seem to be the most effective approach for thermal behavior simulation in the field of building energy management [2].

In this paper, we propose a thermal envelope modeling based on thermal-electrical analogy. The objective is to apply this methodology for calculating indoor temperature of a real platform inside our laboratory building. The necessary parameters have been identified from envelope properties, and they are implemented to generic models in form of equivalent electric circuit. These models are simulated and validated with measurement data. However, our research objective is not only at simulation stage but also to use them for indoor temperature prediction, heating/cooling control and building design, regarding the thermal comfort and the energy efficiency.

\section{THERMAL-ELECTRICAL ANALOGY FOR ENVELOPE MODELING}

The thermal-electrical analogy represents an equivalence between heat transfers and electric currents (TABLE I). This permits to apply the electric current conservation and the ohm's law in order to resolving problems related to thermal balance. In this section, we study applications of thermal-electrical analogy for modeling heat transfers of building envelope which includes opaque elements (walls, roof and floor) and transparent elements (windows and skylight).

TABLE I. THERMAL-ELECTRICAL ANALOGOUS QUANTITIES [3]

\begin{tabular}{|c|c|c|}
\hline Variable & Thermal & Electrical \\
\hline Through variable & $\begin{array}{c}\text { Heat transfer rate, } \\
\mathrm{W}\end{array}$ & $\begin{array}{c}\text { Current, } \\
\mathrm{A}\end{array}$ \\
\hline Across variable & $\begin{array}{c}\text { Temperature, } \\
{ }^{\circ} \mathrm{C} \text { or } \mathrm{K}\end{array}$ & $\begin{array}{c}\text { Voltage } \\
\mathrm{V}\end{array}$ \\
\hline Dissipation element & $\begin{array}{c}\text { Thermal resistance, } \\
{ }^{\circ} \mathrm{C} / \mathrm{W} \text { or K/W }\end{array}$ & $\begin{array}{c}\text { Electric resistance } \\
\Omega\end{array}$ \\
\hline Storage element & $\begin{array}{c}\text { Thermal capacity } \\
\mathrm{J} /{ }^{\circ} \mathrm{C} \text { or } \mathrm{J} / \mathrm{K}\end{array}$ & $\begin{array}{c}\text { Electric capacity } \\
\mathrm{F}\end{array}$ \\
\hline \multicolumn{2}{|c}{} \\
\hline
\end{tabular}




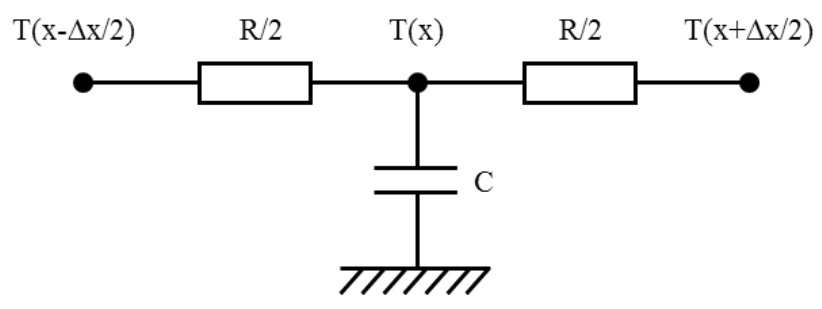

Fig. 1. Electrical analogy of the conduction heat transfer [4]

\section{A. Heat conduction}

In hypothesis of one-dimensional heat conduction, the electrical network of conductive transfers through homogeneous layer could be described in Fig. 1. For an elementary thickness $\Delta \mathrm{x}$, the temperature at length $\mathrm{x}$ is resolved from discrete equation of heat conduction based on the electric current conservation at a corresponding node [4]:

$$
\begin{aligned}
& \frac{T(x+(\Delta x / 2), t)-T(x, t)}{R / 2} \\
& -\frac{T(x, t)-T(x-(\Delta x / 2), t)}{R / 2} \approx C \frac{d T(x, t)}{d t}
\end{aligned}
$$

where, $T$ is the temperature at length $\mathrm{x}[\mathrm{K}]$.

The thermal resistance $\mathrm{R}\left[\mathrm{K} \mathrm{W}^{-1}\right]$ and thermal capacity $\mathrm{C}[\mathrm{J}$ $\mathrm{K}^{-1}$ ] are identified from layer properties:

$$
R=\frac{\Delta x}{\lambda \cdot S_{\text {layer }}}
$$

and

$$
C=\rho \cdot C_{m} \cdot \Delta x \cdot S_{\text {layer }}
$$

where, $\lambda$ is the thermal conductivity $\left[\mathrm{W} \mathrm{m}^{-1} \mathrm{~K}^{-1}\right] . \mathrm{S}_{\text {layer }}$ is the surface of layer $\left[\mathrm{m}^{2}\right] . \rho$ is the mass density of layer materiel $[\mathrm{kg}$ $\left.\mathrm{m}^{-3}\right] . \mathrm{C}_{\mathrm{m}}$ is the specific heat of layer materiel $\left[\mathrm{J} \mathrm{kg}^{-1} \mathrm{~K}^{-1}\right]$.

To reach a simplified model for energy management, we suppose that building envelope is homogeneous. Therefore, the multi-layer wall could be transformed into a two resistances and one capacity model (2R1C). The resistance and capacity of opaque elements $\left(\mathrm{R}_{\text {wall }}\right.$ and $\mathrm{C}_{\text {wall }}$ in Fig. 2$)$ are equivalently identified from resistance and capacity of different layers. Because of low thickness, the thermal capacity of transparent elements is negligible.

\section{B. Heat convection}

The heat convection $\Phi_{\text {conv }}[\mathrm{W}]$ between a surface of building envelope $S$ at temperature $T$ and an air volume at temperature $T_{a}$ is defined as [4]:

$$
\Phi_{\text {conv }}=h_{s} . S .\left(T-T_{a}\right)
$$

where, $\mathrm{h}_{\mathrm{c}}$ is the convective heat transfer coefficient $\left[\mathrm{J} \mathrm{m}^{-2} \mathrm{~K}^{-1}\right]$.

From this, the convective resistance $\mathrm{R}_{\text {conv }}$ is expressed as:

$$
R_{c o n v}=\frac{1}{h_{c} \cdot S}
$$

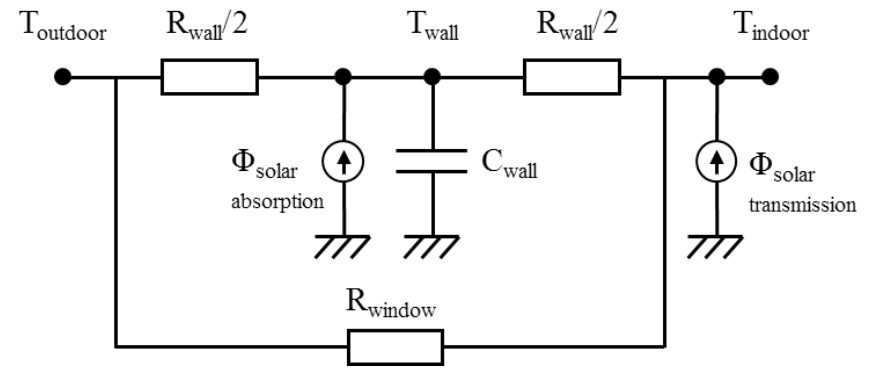

Fig. 2. Electrical analogy of wall thermal model

The conductive resistance need to be added to thermal resistance of layer $\left(R_{\text {wall }} / 2\right.$ and $R_{\text {windows }}$ in Fig. 2$)$ which contact with indoor or outdoor ambient.

\section{Ventilation}

In buildings, air ventilation is important to displace indoor pollutants and supply fresh air for indoor air quality. The heat flow rate due ventilation is given by [5]:

$$
\Phi_{\text {conv }}=\rho_{a} \cdot V_{r} \cdot C_{a} \cdot\left(T_{\text {outdoor }}-T_{\text {indoor }}\right)
$$

where, $\rho_{\mathrm{a}}$ is the mass density of air $\left[\mathrm{kg} \mathrm{m}^{-3}\right] . \mathrm{V}_{\mathrm{r}}$ is the ventilation rate or air flow $\left[\mathrm{m}^{3} \mathrm{~h}^{-1}\right] . \mathrm{C}_{\mathrm{a}}$ is the specific heat of air $\left[\mathrm{J} \mathrm{kg}^{-1} \mathrm{~K}^{-1}\right]$. $\mathrm{T}_{\text {indoor }}$ and $\mathrm{T}_{\text {outdoor }}$ is the indoor and outdoor temperature $[\mathrm{K}]$.

The thermal resistance of air flow $\mathrm{R}_{\mathrm{vent}}\left[\mathrm{K} \mathrm{W}^{-1}\right]$ is deduced as:

$$
R_{v e n t}=\frac{1}{\rho_{a} \cdot V_{r} \cdot C_{a}}
$$

\section{Solar heat gain}

Solar radiation heats the building, either directly through transparent elements, or indirectly through opaque elements [6]. Its impacts to building envelope are represented in Fig. 2.

The heat source due solar absorption of opaque elements is given by:

$$
\Phi_{\text {solar absorption }}=\alpha \cdot G \cdot S .(1-W W R)
$$

where, $\alpha$ is the solar absorptance. $\mathrm{G}$ is the solar radiation of wall surface $\left[\mathrm{W} \mathrm{m}^{-2}\right]$. WWR is the wall windows ratio.

The heat source due solar transmission through transparent elements could be written as:

$$
\Phi_{\text {solar transmission }}=S H G C \cdot G \cdot \beta \cdot S \cdot W W R
$$

where, SHGC is the solar heat gain coefficient. $\beta$ is the shading coefficient.

\section{CASE STUDY PREDIS: MODELING AND SIMULATION}

The PREDIS MHI platform (Monitoring et Habitat Intelligent), situated inside Grenoble Electrical Engineering Laboratory, is our research object in this paper. This platform is a prototype of low energy building which is used for testing and applying our researches of building energy management on real system. In this section, we study an application of electricalthermal analogy for thermal envelope modeling of this platform. 


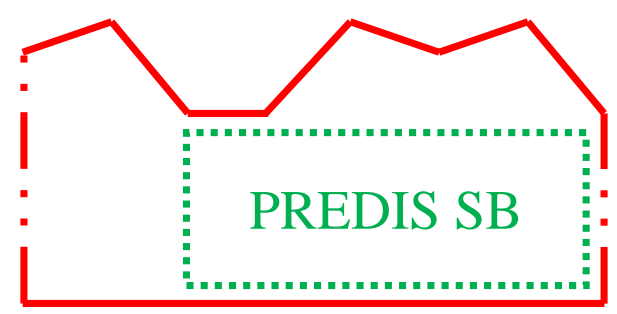

Fig. 3. PREDIS Smart Building

\section{A. PREDIS MHI platform}

For us, the "building inside a building" concept is very helpful to assess thermal behavior of specific thermal zones of building which are impacted by different thermal zones surrounded. This is the reason why the PREDIS MHI platform was constructed inside another building (Fig. 3). In fact, it has been renovated from an old building by improving walls insulation and installing an HVAC dual flow.

The main thermal insulation is cellulose wadding $(14 \mathrm{~cm})$, which was installed on a wooden cladding that surrounds both interior and exterior walls of the platform. However, the intermediate floor composition was unchanged as part of the original foundation. Materials and HVAC system have been chosen so that the building's maximal energy consumption did not exceed 50kWhPE (Primary Energy) $/\left(\right.$ year.m $\left.{ }^{2}\right)$, in order to respect low energy buildings restrictions [7].

The first floor of this building, our experimental local, includes two rooms: classroom and researcher's office (Fig. 4). The classroom is used for training courses of Grenoble University and equipped with laptops which are connected to the electrical grid and photovoltaic generators. The researcher's office, where the control, supervision and measurement devices are installed, is daily occupied by about six researchers.
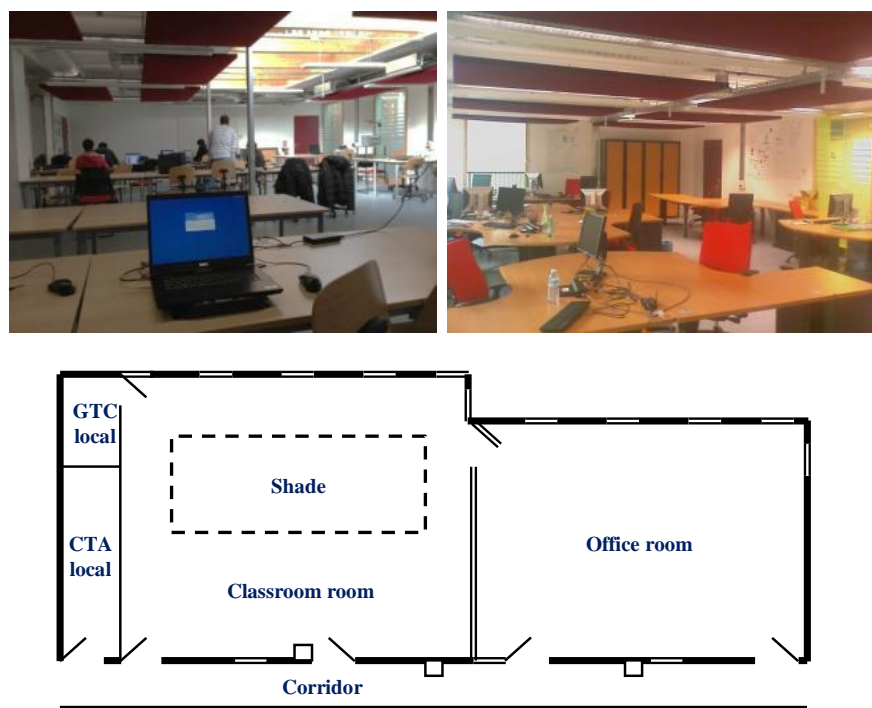

Fig. 4. Classroom and Office

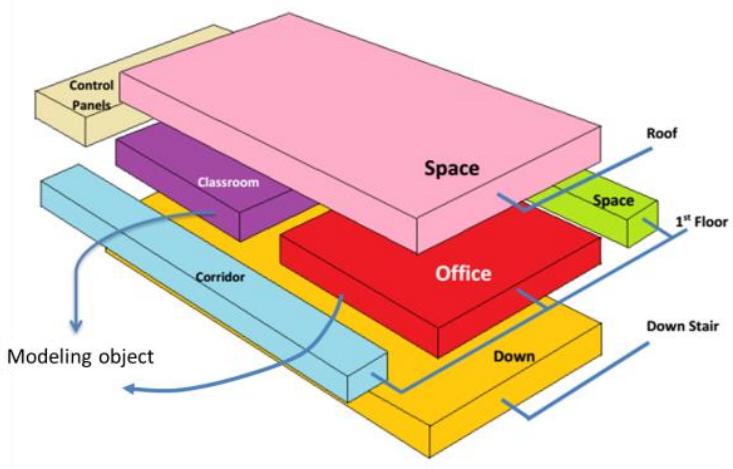

Fig. 5. 3D overview of PREDIS MHI platform

\section{B. Development of envelope model}

In Fig. 5, the 3D overview represents two thermal zones of PREDIS MHI platform corresponding to classroom and office. They are surrounded by the following thermal zones [8]:

- Space over the ceiling named Shade

- Adjacent space on two sides of this platform named Void

- Corridor zone

- Space of ground floor

- Two technical areas named GTC local and CTA local

Walls, floor and ceiling of classroom and office are modeled as 2R1C models (Fig. 2). Their parameters have been identified from envelope properties which was descripted in architect design. Therein, thermal capacity of room ambience is estimated from air volume and furniture material.

TABLE II. PARAMETERS OF CLASSROOM'S ENVELOPE MODEL

\begin{tabular}{|c|c|c|c|c|}
\hline \multirow[b]{2}{*}{$\begin{array}{c}\text { Envelope } \\
\text { side }\end{array}$} & \multicolumn{2}{|c|}{ Wall/Floor/Ceiling } & \multirow{2}{*}{$\begin{array}{c}\text { Windows } \\
\text { Thermal } \\
\text { resistance } \\
{\left[K W^{-1}\right]}\end{array}$} & \multirow{2}{*}{$\begin{array}{c}\text { Ambience } \\
\text { Thermal } \\
\text { capacity } \\
{\left[J \mathrm{~K}^{-1}\right]}\end{array}$} \\
\hline & $\begin{array}{c}\text { Thermal } \\
\text { resistance } \\
{\left[K W^{-1}\right]}\end{array}$ & $\begin{array}{c}\text { Thermal } \\
\text { capacity } \\
{\left[J K^{-1}\right]}\end{array}$ & & \\
\hline Corridor & 0.0363 & $1.22 \mathrm{e} 7$ & 0.2226 & \multirow{7}{*}{$1.2 \mathrm{e} 7$} \\
\hline Void & 0.144 & $7.49 \mathrm{e} 6$ & 0.0399 & \\
\hline G floor & 0.0069 & $3.63 \mathrm{e} 7$ & - & \\
\hline Office & 0.0776 & $1.42 \mathrm{e} 6$ & 0.0254 & \\
\hline Shade & 0.0448 & $2.13 \mathrm{e} 6$ & 0.0313 & \\
\hline GTC & 0.0772 & $0.97 \mathrm{e} 6$ & - & \\
\hline CTA & 0.042 & $2.53 \mathrm{e} 6$ & - & \\
\hline
\end{tabular}

TABLE III. PARAMETERS OF OFFICE'S ENVELOPE MODEL

\begin{tabular}{|c|c|c|c|c|}
\hline \multirow[b]{2}{*}{$\begin{array}{l}\text { Envelope } \\
\text { side }\end{array}$} & \multicolumn{2}{|c|}{ Wall/Floor/Ceiling } & \multirow{2}{*}{$\begin{array}{c}\text { Windows } \\
\text { Thermal } \\
\text { resistance } \\
{\left[K W^{-1}\right]}\end{array}$} & \multirow{2}{*}{$\begin{array}{c}\text { Ambience } \\
\text { Thermal } \\
\text { capacity } \\
{\left[J K^{-1}\right]}\end{array}$} \\
\hline & $\begin{array}{c}\text { Thermal } \\
\text { resistance } \\
{\left[K W^{-1}\right]}\end{array}$ & $\begin{array}{c}\text { Thermal } \\
\text { capacity } \\
{\left[\mathrm{J} \mathrm{K} \mathrm{K}^{-1}\right]}\end{array}$ & & \\
\hline Corridor & 0.045 & $8.9 \mathrm{e} 6$ & 0.1373 & \multirow{5}{*}{$7.03 \mathrm{e} 6$} \\
\hline Void & 0.1071 & $7.8 \mathrm{e} 6$ & 0.0455 & \\
\hline G floor & 0.0107 & $2.3 \mathrm{e} 7$ & - & \\
\hline Classroom & 0.0776 & $1.42 \mathrm{e} 6$ & 0.0254 & \\
\hline Shade & 0.0689 & $1.37 \mathrm{e} 6$ & - & \\
\hline
\end{tabular}




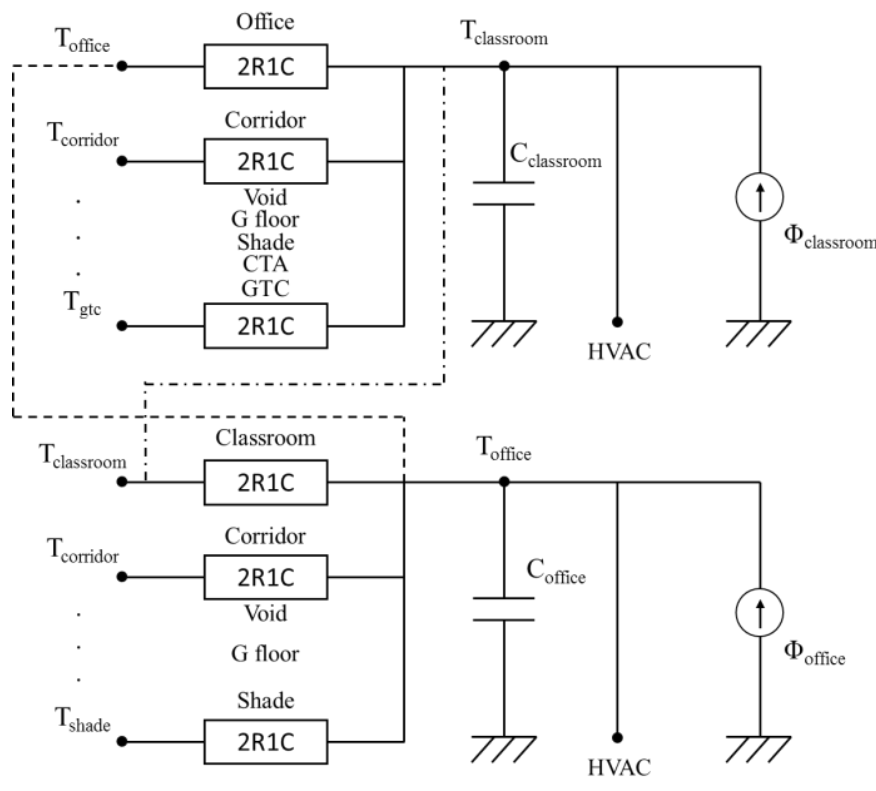

Fig. 6. Envelope model of PREDIS MHI platform

These parameters are implemented to generic models in form of an equivalent electric circuit shown in Fig. 6. In this model, solar radiation and interior heating have to be taken in to account, but the thermal bridges and air leakage have been neglected. This model is also allowed to connect to HVAC model for building energy simulation.

For simulation, this electrical circuit has been integrated to SimPowerSystem - a toolbox of Matlab/Simulink. Then, the model equations are automatically generated in form of time integration and solved by using the solver of Bogacki-Shampine (ode3).

$$
A \cdot T(t)=B . U(t)+C . T(t-\Delta t)
$$

where, $\mathrm{T}(\mathrm{t})$ and $\mathrm{T}(\mathrm{t}-\Delta \mathrm{t})$ contain indoor air temperature and wall temperatures at time $\mathrm{t}$ and $\mathrm{t}-\Delta \mathrm{t}$. $\mathrm{U}(\mathrm{t})$ is input vector that includes heat gains and temperature of adjacent zones. A, B and $\mathrm{C}$ are the matrix that represents electrical circuit elements.

\section{Simulation and Validation}

Thanks to the supervisor system of PREDIS MHI platform, the measurement data during a period in 2013 (from Nov 14 to Dec 4) is used for our simulation. Because of lacking radiation sensors, this period is chosen in winter for avoiding impacts of solar radiation.

Fig. 7 represents temperature of adjacent zones surrounded the PREDIS MHI platform. Fig. 8 descripts air temperature and flow given by HVAC system. Fig. 9 is the interior heating that includes sources of gain from heating devices, occupants and electric equipment. They are used as input variables of this envelope model and validation data.

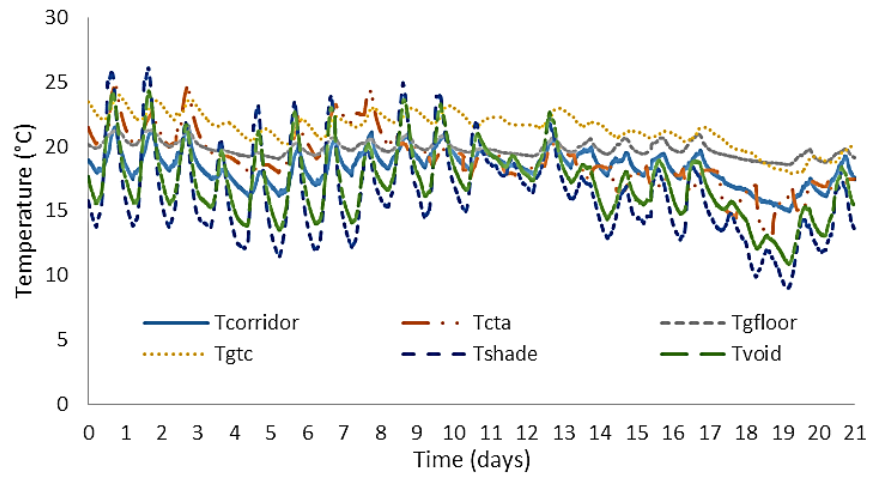

Fig. 7. Temperature of adjacent zones

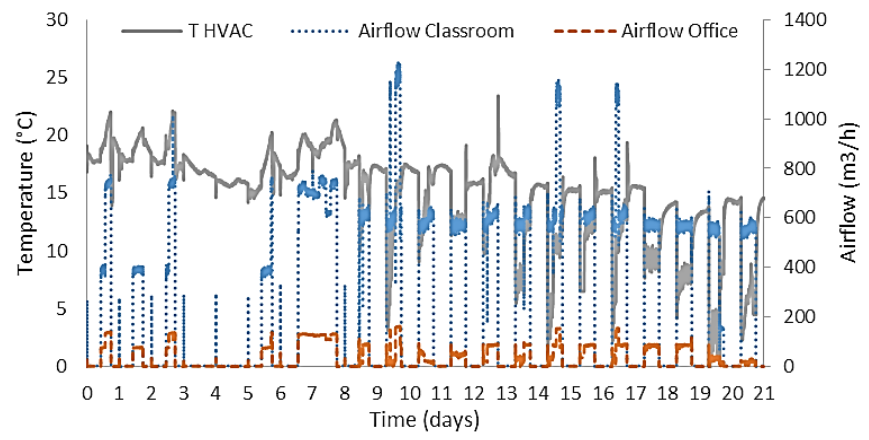

Fig. 8. Data of HVAC system

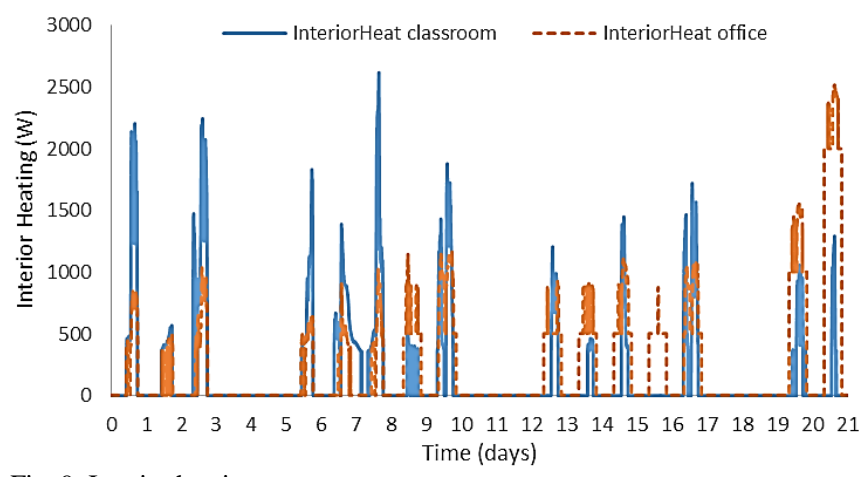

Fig. 9. Interior heating

The model is simulated during three weeks with time steps of 60 seconds in Matlab/Simulink. The results are given in Fig. 10 and Fig. 11 in comparison with measured temperatures. The average error of this envelope model is about $0.5^{\circ} \mathrm{C}$ and thermal behavior is well matched measured form.

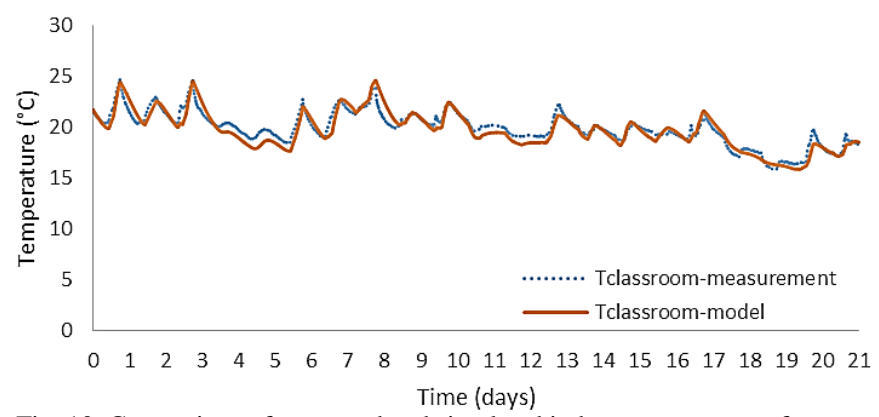

Fig. 10. Comparison of measured and simulated indoor temperature of classroom 


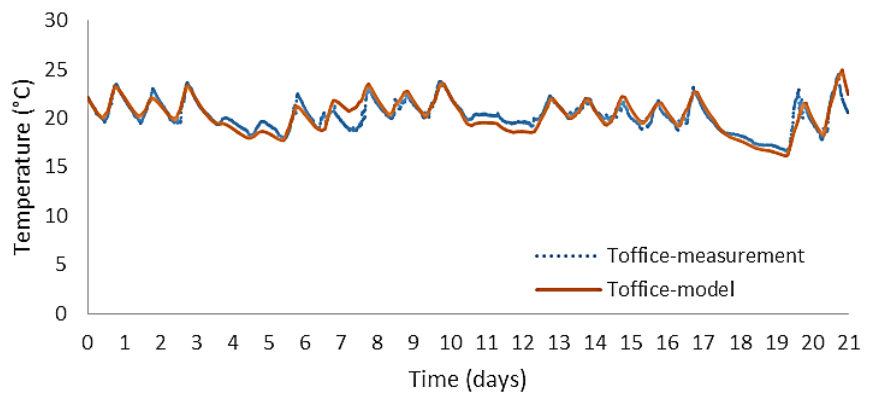

Fig. 11. Comparison of measured and simulated indoor temperature of office

\section{CONCLUSION}

This paper represents a thermal envelope modeling based on thermal-electrical analogy and its application for PREDIS MHI platform. The envelope model is built in form of equivalent electric circuit so that we can apply the electric current conservation and the ohm's law for calculating indoor temperatures. The results justify that this model is enough accurate for energy building simulation.

Furthermore, this envelope model must not only be used for simulation but also applicable for optimization. Indeed, it will be used for indoor temperature prediction and heating/cooling control, regarding the thermal comfort and the energy efficiency. Moreover, it could be used as a sizing tool for designing a virtual building envelope before construction.

\section{REFERENCES}

[1] H. Park, M. Ruellan, N. Martaj, R. Bennacer and E. Monmasson, "Generic Thermal Model of Electric," IECON 2012 - 38th Annual Conference on IEEE Industrial Electronics Society, Montreal, QC, pp. 3318 - 3323, 25 28 Oct. 2012.

[2] F. Amara, K. Agbossou, A. Cardenas, Y. Dube and S. Kelouwani, "Comparision and Simulation of Building Thermal Models for Effective Energy Management,” Smart Grid and Renewable Energy, vol. 6, pp 95 - 112, Scientific Research Publising Inc, 30 Apr. 2015.

[3] G. Swift, T. S. Molinski and W. Lehn, "A Fundamental Approach to Transformer Thermal Modeling-Part I: Theory and Equivalent Circuit," IEEE Transactions on Power Delivery, vol. 16, No. 2, Apr. 2001.

[4] G. Fraisse, C. Viardot, O. Lafabrie and G. Achard, "Development of a simplified and accurate building model based on electrical analogy," Energy and Building, vol. 34, pp 1017-1031, Elsevier Science B.V., 2 Feb. 2002.

[5] Government of India, Ministry of New and Renewable Energy (MNRE), (http://mnre.gov.in/solar-energy/ch4.pdf)

[6] Vietnam Ministry of Construction, "National Technical Code for Building Energy Efficiency," Sept. 2005.

[7] H. A. Dang, S. Gaaloul, B. Delinchant |F. Wurtz, "Building Simulation Of Energy Consumption And Ambient Temperature: Application To The PREDIS Platform," Building Simulation 2013, Chambery, France, 26-28 Aug. 2013.

[8] S. Sarabi, S. Ploix, M. H. Le, H. A. Dang, F. Wurtz, "Assessing The Relevance Of Reduced Order Models For Building Envelop,” Building Simulation 2013, Chambery, France, 26-28 Aug. 2013. 